\title{
Vegetation Changes from 1935 to 1980 in Mesquite Dunelands and Former Grass- lands of Southern New Mexico
}

\author{
J.T. HENNESSY, R.P. GIBBENS, J.M. TROMBLE, AND M. CARDENAS
}

\begin{abstract}
On the Jornada Experimental Range in southern New Mexico, 2 belt transects, $30.5 \mathrm{~cm}$ in width and totaling $2,188 \mathrm{~m}$ in length, were established in 1935 on 2 areas where honey mesquite (Prosopis glandulosa Torr.) was spreading into black grama [Bouteloua eriopoda (Torr.) Torr.] grassland. Maps were made of the transects which portrayed the vegetation occurring in each of the 7,180 contiguous, $0.09-\mathrm{m}^{2}$ plots along the transect. The vegetation on the transects in 1980 was compared to that portrayed by the transect maps made in 1935. One transect had been read in 1950 and 1955. During the 45-year period mesquite attained complete dominance and many new mesquite dunes formed. Black grama had a relatively high frequency in 1935 but had completely disappeared by 1980 , both on an area grazed by livestock and on an area protected from grazing. Mesa dropseed [Sporobolus flexuosus (Thurb.) Rydb.], fluffgrass [Erioneuron pulchellum (H.B.K.) Tateoka] and broom snakeweed [Xanthocephalum sarothrae (Pursh) Shinners] increased in abundance, even during the drought period between 1950 and 1955 . Only $25 \%$ of the perennial forb species encountered in 1935-55 were found in $\mathbf{1 9 8 0}$.
\end{abstract}

The spread of honey mesquite (Prosopis glandulosa Torr.) and other shrubs in the Southwest has been well documented, with heavy grazing, seed dispersal by domestic animals and periodic droughts being advanced as causes contributing to the increase in shrubs (Buffington and Herbel 1965; York and Dick-Peddie 1969). Mesquite has many features which enable it to exploit altered ecosystems. These include rapidly developing, deep taproots and long lateral roots, long-lived seeds, high germination rates over a wide range of temperature and moisture conditions, ability to withstand high negative water potentials, high water use efficiency, and the ability to regenerate from underground dormant buds following injury (Glendening and Paulsen 1955, Mooney et al. 1977).

Mesquite has increased in abundance on a wide range of soil types but in southern New Mexico its greatest increase has been on sandy soils (Buffington and Herbel 1965). In arid areas mesquite typically grows as a low multi-stemmed shrub. These multistemmed plants entrap drifting sand, forming what has been called "coppice dunes" (Melton 1940). Vast areas of former desert grassland have been transformed into hummocky landscapes dominated by mesquite dunes. Dunes large enough to class as pedons have developed soils which are distinct from those of the interdunal areas (Giles 1966). Mesquite dunelands have an appearance of stability but considerable soil movement was found over a 45 -year period (Gibbens et al. 1983). The transformation of desert grasslands into dynamic dunelands has resulted in the complete loss of

\footnotetext{
Authors are respectively, former graduate student, Department of Animal and Range Science. New Mexico State Univ., Las Cruces 88003, now Range Science Officer, Gaburone, Botswanna, Africa; range scientist and hydrologist, USDA, Agricultural Research Service, Las Cruces, N. Mex. 88004; and associate professor, Department of Experimental Statistics, New Mexico State Univ., Las Cruces.

This report is published as journal article 905, Agricultural Experiment Station, New Mexico State Univ., Las Cruces.
}

some former dominant plants and in major shifts in abundance of other herbaceous plants.

Early researchers at the Jornada Experimental Range in southcentral New Mexico witnessed the encroachment of mesquite into desert grasslands. They established belt transects across mesquitegrassland ecotones and made detailed records of the existing vegetation. During the ensuing years mesquite continued to increase in abundance. A comparison of present with past vegetation on the transects provides much insight on the reactions of grassland species to an increase of mesquite. This information is of value both in an ecological sense and in managing mesquite-dominated lands as a grazing resource.

\section{Study Area}

The Jornada Experimental Range, located $37 \mathrm{~km}$ north of Las Cruces, N. Mex., includes 78,266 ha characterized by basin range topography representative of the northern Chihuahuan Desert. About 58,470 ha of relatively level plain forms the floor of a closed basin at an elevation of $1,260 \mathrm{~m}$. Mesquitc occurs on about $63 \%$ of the plain and large dunefields have formed on the predominately sandy soils (Buffington and Herbel 1965).

The climate is arid, with an average annual precipitation of 231 $\mathrm{mm}$. Precipitation is concentrated in July, August, and September when $52 \%$ of the annual total occurs. Summer rainfall usually occurs as intense, convective thunderstorms which are of short duration and highly localized. In winter, low-intensity precipitation originates from frontal storms that cover wide areas. The frost-free period averages 200 days but vegetation growth is usually limited to a shorter period when soil water is available.

In 1933, a 259-ha (640 acres) exclosure was built on an area partially occupied by mesquite. The exclosure was established to determine if protection from grazing would allow natural plant succession to reestablish a grassland climax. Originally called the "Natural Revegetation Exclosure", this will henceforth be designated as Site A. The relatively deep, loamy sands in this area are mapped as thermic Typic Haplargids of the Onite series. Soils in the mesquite dunes are thermic Typic Torripsamments of the Pintura series (Bullock and Neher 1980). An intensive reconnaissance survey was made of the site in 1932 and a vegetation type map prepared. In 1935, a $1,731-\mathrm{m}$ belt transect, $30.5 \mathrm{~cm}$ in width, with stakes every $15.2 \mathrm{~m}$, was laid out in a north-south direction across the exclosure and projecting $61 \mathrm{~m}$ beyond the boundary fences.

On an area designated as Site B, a $457.2-\mathrm{m}$ belt transect, $30.5 \mathrm{~cm}$ in width was established across a mesquite duneland-grassland ecotone in 1935. Half of the transect fell in mesquite duneland and half in grassland. Marker stakes were placed every $15.2 \mathrm{~m}$. The transect is located on shallow ( $\angle 50 \mathrm{~cm}$ to caliche layer), thermic Typic Paleorthids of the Simona serics (Bullock and Neher 1980). Dunes large enough to qualify as pedons belong to the Pintura series.

In 1966-68, approximately one-third of the Site A exclosure was 
sprayed with $2,4,5-T$ in mesquite control tests. Second applications of 2,4,5-T as plot treatments were superposed upon the sprayed portion in 1969-72. Approximately $183 \mathrm{~m}$ of the Site B transect fell within an area treated with a single application of 2,4,5-T in 1973.

\section{Methods}

In 1932 a vegetation type map (scale, 16 inch $=1$ mile) was made of the Site A exclosure. The transect established across Site A in 1935 followed a north-south grid line $604 \mathrm{~m}$ from the west side of the exclosure. A map of the number and species of plants occurring in each of the 5,680 contiguous $0.09 \mathrm{~m}^{2}(30.5 \times 30.5 \mathrm{~cm})$ plots along the transect was made at a scale of $1.02 \mathrm{~cm}=30.5 \mathrm{~cm}(.4 \mathrm{inch}=1$ $\mathrm{ft}$ ). Mesquite dune outlines and profiles were also mapped. The Site B transect was mapped in the same manner. In 1950 and 1955 the Site B transect was remeasured and a record made of all the plants occurring in each of the 1,500 contiguous, $30.5 \times 30.5-\mathrm{cm}$ plots. In 1980, both the Site A and Site B transects were remeasured. All perennial vegetation was recorded for each of the 0.09 $\mathrm{m}^{2}$ plots along the transects. Because a road (present in 1935) crosses the Site B transect, data from $30.5-\mathrm{m}$ of the transect have been discarded. Density and frequency of plant species on dune and interdune areas were determined from the original 1935 transect maps, from the 1950 and 1955 field sheets and from the 1980 field sheets. Species frequencies are greatly influenced by the size of plots used to determine them. The $0.09-\mathrm{m}^{2}$ plots sampled in 1935 and 1980 are much smaller than would normally be used for determining the frequency of perennial species in the mesquite sand dune vegetation type. However, it should be remembered that the small plots do represent a $100 \%$ sample of the area of interest, i.e., a strip of land $30.5 \mathrm{~cm}$ wide and the length of the transects. The species frequencies used below to make comparisons within a transect or between years apply only to the $0.09-\mathrm{m}^{2}$ plots used on the belt transects and should not be construed as representing a "true" frequency for the species in the vegetation type as a whole. Nomenclature follows Correll and Johnston (1970).

\section{Results and Discussion}

Before evaluating vegetation changes over time, it was necessary to determine if the herbicide treatments had caused appreciable changes in the vegetation. There were $1,128 \mathrm{~m}$ of the Site A transect within the herbicide treatments. Discarding $30.5-\mathrm{m}$ of data on either side of the herbicide plot boundary, comparisons were made of frequency percentages of the most abundant species in 1980 on treated and nontreated areas.

Mesa dropseed [Sporobolus flexuosus (Thurb.) Rydb.] was the most abundant grass and one which often increases in abundance following mesquite control (Herbel and Gould 1970). In 1980, the frequency of mesa dropseed on treated and nontreated portions of the transect was $11.0 \%$ and $12.8 \%$, respectively. Rooted frequency of mesquite was $15.3 \%$ on the treated portion of the transect and $15.0 \%$ on the nontreated portion. The canopy frequency of mesquite was $27.0 \%$ and $25.9 \%$ on the treated and nontreated portions of the transect, respectively. A $t$-test of the mean frequencies per 15.2-m transect segments on the treated and nontreated portions of the transect did not show significant differences $(P>.05)$ in the frequency of mesa dropseed and rooted or canopy frequency of mesquite. Broom snakeweed [Xanthocephalum sarothrae (Pursh) Shinners] had frequencies of $18.4 \%$ and $7.2 \%$ on treated and nontreated portions of the transect, respectively. The mean frequencies of broom snakeweed per 15.2-m line segments were significantly different $(P>.05)$ on the treated and nontreated portions of the transect. While the difference in abundance of broom snakeweed may be the result of the herbicide treatment, it is equally likely that it is a reflection of the typical patchy occurrence of this species.

The comparisons of the treated and nontreated portions of the transect supported field observations indicating the effect of the herbicide treatments had been minimal in the vicinity of the transect. Also, there were no visible differences in grazed and non- grazed portions of the transect. It was concluded that the transect could be analyzed as an entity for comparison with 1935 records.

The portion of the Site B transect which had been sprayed with herbicide was compared to the nonsprayed portion, again discarding the boundary area. The frequency of mesa dropseed was $16.5 \%$ and $20.4 \%$ on treated and nontreated portions of the transect, respectively. Broom snakeweed had a frequency of $28.7 \%$ on the treated portion and $30.0 \%$ on the nontreated portion. Rooted frequency of mesquite was $18.2 \%$ and $9.7 \%$ on the treated and nontreated portions of the transect, respectively. Canopy frequency of mesquite was $34.7 \%$ and $24.0 \%$ on treated and nontreated portions of the transect, respectively. Comparisons of mean frequencies per 15.2-m transect segments of mesa dropseed, broom snakeweed, and mesquite by a $t$-test did not show any significant differences $(P>.05)$ between treated and nontreated portions of the transect. The effects of the herbicide treatment were judged to be minimal and comparisons over time were made without consideration of the herbicide application.

On the 1932 vegetation type map of Site A, 40 types were delineated and the composition and cover of plant species given for each type. The large number of types resulted from the practice of mapping as separate types areas differing in cover percentage, even though the dominant plant species were the same.

Mesquite was represented in all of the types mapped, ranging from $3-93 \%$ of the species composition. On slightly over half of the area, mesquite made up $50 \%$ or more of the species composition. Broom snakeweed was the second most abundant species and was also found in all of the types. Black grama [Bouteloua eriopoda (Torr.) Torr.] contributed $1-44 \%$ of the species composition on 162 ha. However, black grama and other grasses were the major domi-
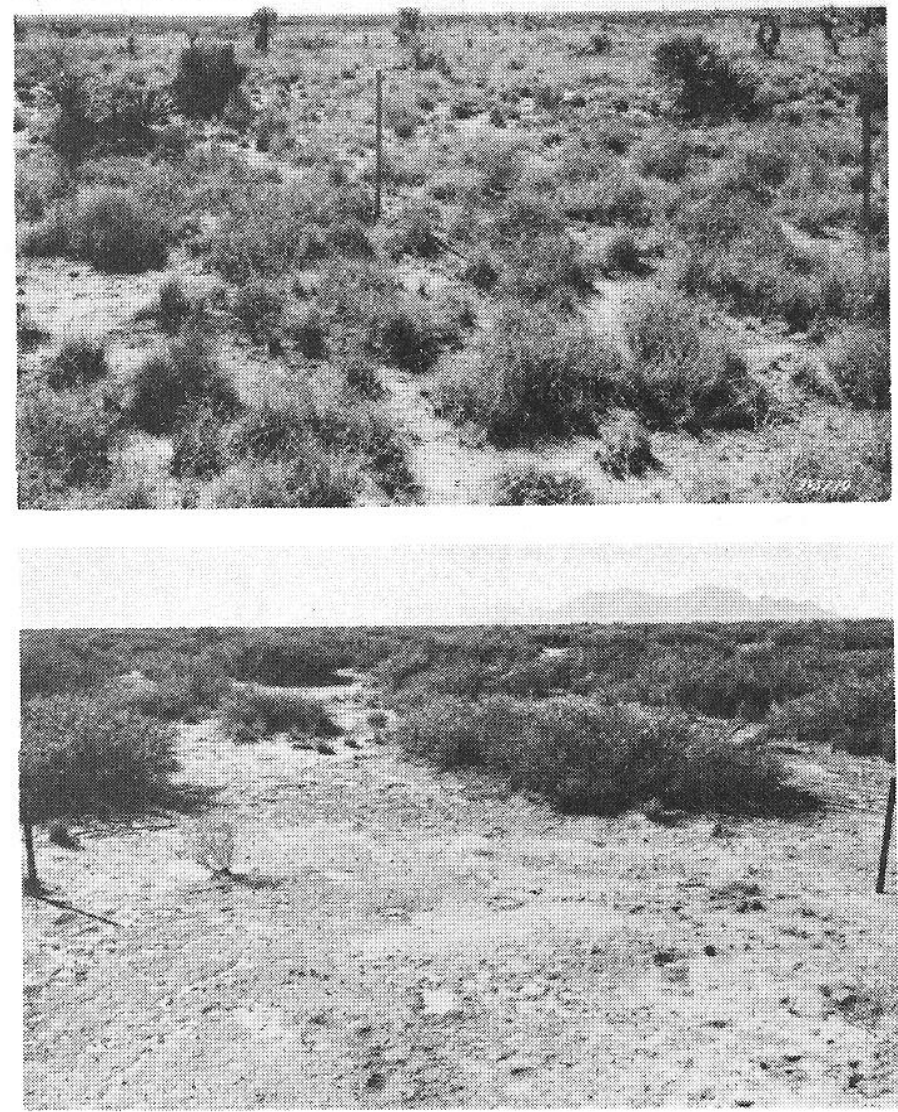

Fig. 1. View of the Site A exclosure in 1934 (top) and 1980 (bottom). Mesquite dunelands have completely replaced a black grama grassland. Top view is U.S. Forest Service photo by J.T. Cassady, bottom view is by R.P. Gibbens. 
nants on only 9 ha. The picture portrayed by the type map is one of an area where mesquite was in the process of occupying a former grassland. The change in appearance of grass-dominated areas is illustrated in Figure 1.

The formation of mesquite dunes creates a habitat for plants which is different from that of interdunal areas. Hence, the Site $A$ transect data for 1935 and 1980 has been separated into dune and interdune areas (Table 1). During the 45-year period the area in mesquite dunes more than doubled. On the transect as a whole, frequency of mesquite canopy increased from $12.1 \%$ in 1935 to $26.2 \%$ in 1980 .

On the Site A transect, black grama and threeawns (Aristida spp.) have disappeared from both dune and interdune areas (Table 1). Black grama cannot now be found in the 259-ha exclosure and very few plants of threeawn are present. Fluffgrass [Erioneuron pulchellum (H.B.K.) Tateoka] increased on interdunal areas and mesa dropseed increased on both dune and interdunal areas (Table 1). In 1935, mesa dropseed densities were equivalent to 0.6 and 0.5 plants per $\mathrm{m}^{2}$ on dune and interdune areas, respectively. In 1980 , mesa dropseed densities were equal to 2.8 and 1.4 plants per $\mathrm{m}^{2}$ on dune and interdune areas, respectively.

Both fluffgrass and mesa dropseed are relatively short-lived perennials (Dittberner 1971) and their populations fluctuate with favorable or unfavorable climatic conditions. Although rainfall in 1935 was above average $(279 \mathrm{~mm})$, the populations of fluffgrass and mesa dropseed were probably at a low level because of the severe drought (132 $\mathrm{mm}$ of rainfall) which occurred in 1934 (Paulsen and Ares 1962). The 1980 sampling followed a series of favorable years (1977-80) when rainfall ranged from $214-396 \mathrm{~mm}$ and fluffgrass and mesa dropseed populations were at a relatively high level.

Only 2 of the 7 species of perennial forbs present on the transect in 1935 were encountered in 1980 (Table 1). The reduction in forb species is real but it is not possible to quantify it precisely. Not all forbs were identified in 1935 and some of the unidentified plants may have been perennials. The perennial forb populations were very sparse in both 1935 and 1980 . The average density of all forb species on dune and interdune areas combined was equivalent to 0.4 and 0.2 plants per $\mathrm{m}^{2}$ in 1935 and 1980 , respectively.
One shrubby species, four-wing saltbush [Atriplex canescens (Pursh) Nutt.], was encountered on the transect in 1980 but not in 1935. On the 1932 type map four-wing saltbush is listed as occurring in trace amounts on $\mathbf{1 5 8}$ ha, primarily in types where mesquite made up $80 \%$ or more of the species composition. The four-wing saltbush plants typically grow on mesquite dunes and the increase in number of mesquite dunes during the 45 -year period has been accompanied by an increase in four-wing saltbush. The shrubs are now found throughout the exclosure.

The shrub-like soaptree yucca (Yucca elata Engelm.) made up $1-5 \%$ of the species composition in all of the 40 types in 1932. In 1980 , only a few individuals of soaptree yucca were observed in the exclosure. Broom snakeweed was slightly more abundant in 1980 than in 1935. On the interdune areas broom snakeweed densities were equivalent to 2.3 and 3.3 plants per $\mathrm{m}^{2}$ in 1935 and 1980 , respectively. Since broom snakeweed populations cycle from high to low, little can be concluded except that the 1935 and 1980 samples were taken in years with similar broom snakeweed populations.

For the Site B transect, the vegetation types present in 1935, i.e, mesquite duneland and black grama grassland, have been used as a base for following changes through years (Table 2). Dune and interdune areas are not presented because the actual extent of dunes was not recorded in 1950 or 1955.

On the mesquite duneland portion of the transect, mesquite canopy frequency doubled between 1935 and 1980 (Table 2). Over half of the increase in canopy frequency occurred between 1935 and 1950 . The increase in mesquite canopy reflects the formation of new dunes and an increase in the size of dunes present in 1935.

Black grama had a relatively high frequency $(27.2 \%)$ in 1935 but was only about half as abundant in 1950. By 1955, the frequency of black grama was only $0.9 \%$ and none was found in 1980 , either on the transect or in the vicinity. Mesa dropseed increased in frequency from $6.3 \%$ in 1935 to $15.5 \%$ in 1980 . Mesa dropseed in 1980 had a higher frequency on dunes $(18.2 \%)$ than on interdune areas (13.2\%). In 1980, densities of mesa dropseed were equivalent to 2.6 and 1.8 plants per $\mathrm{m}^{2}$ on dune and interdune areas, respectively. Fluffgrass, not present in 1935 or 1950 , had a higher density and frequency than mesa dropseed in 1980 but was found primarily on

Table 1. Frequency percentage of perennial plant species in $0.09 \mathrm{~m}^{2}$ plots on dune and interdune areas of the Site $A$ transect in 1935 and 1980.

\begin{tabular}{|c|c|c|c|c|}
\hline & \multicolumn{2}{|c|}{ Dune area } & \multicolumn{2}{|c|}{ Interdune area } \\
\hline & $\begin{array}{c}1935 \\
(N=932)\end{array}$ & $\begin{array}{c}1980 \\
(N=1906)\end{array}$ & $\begin{array}{c}1935 \\
(\mathrm{~N}=4748)\end{array}$ & $\begin{array}{c}1980 \\
(\mathrm{~N}=3774)\end{array}$ \\
\hline \multicolumn{5}{|l|}{ Grasses } \\
\hline Aristida spp. & .4 & 0 & 3.4 & 0 \\
\hline $\begin{array}{l}\text { Bouteloua eriopoda (Torr.) Torr. } \\
\text { Erioneuron pulchellum (H.B.K.) }\end{array}$ & .1 & 0 & 8.4 & $\mathbf{0}$ \\
\hline Tateoka & 0 & .3 & .1 & 6.1 \\
\hline Muhlenbergia porteri Scribn. & 2.3 & .2 & $T^{1}$ & TI \\
\hline Setaria macrostachya H.B.K. & .3 & .2 & 0 & 0 \\
\hline $\begin{array}{l}\text { Sporobolus flexuosus (Thurb.) } \\
\text { Rydb. }\end{array}$ & 5.2 & 17.4 & 4.4 & 9.4 \\
\hline \multicolumn{5}{|l|}{ Forbs } \\
\hline Astragalus spp. & 0 & 0 & .1 & 0 \\
\hline Caesalpinia jamesii (T. \& G.) Fisher & 0 & 0 & .1 & 0 \\
\hline Cassia bauhinioides Gray & 0 & .2 & .2 & 1.9 \\
\hline Euphorbia albomarginata T. \& G. & $\mathbf{0}$ & 0 & .2 & 0 \\
\hline Hymenopappus robustus Greene & $\mathbf{0}$ & 0 & 1.9 & 0 \\
\hline Mentzelia multiflora (Nutt.) Gray & 0 & 0 & .2 & 0 \\
\hline Sphaeralcea incana Torr. & 0 & .1 & .8 & .1 \\
\hline \multicolumn{5}{|l|}{ Shrubs and shrub-like plants } \\
\hline Atriplex canescens (Pursh) Nutt. & $\mathbf{0}$ & .5 & 0 & $\mathrm{~T}^{\mathbf{I}}$ \\
\hline Prosopis glandulosa Torr. & 71.32 & $70.0^{2}$ & $.6^{2}$ & $4.1^{2}$ \\
\hline $\begin{array}{l}\text { Yucca elata Engelm. } \\
\text { Xanthocephalum sarothrae (Pursh) }\end{array}$ & .1 & $\mathbf{0}$ & .5 & 0 \\
\hline Shinner & 1.8 & 3.2 & 15.6 & 14.2 \\
\hline
\end{tabular}

$1 \mathrm{~T}=$ Trace (less than $.05 \%)$

${ }^{2}$ Frequency percentage of mesquite canopy. Rooted frequency of mesquite could not be determined from 1935 transect map. 
interdune areas. Fluffgrass densities were equivalent to 3.9 plants per $\mathrm{m}^{2}$ on the interdune areas and 0.6 plants per $\mathrm{m}^{2}$ on dunes.

Forbs were not abundant on the mesquite duneland portion of the tran sect at any sampling date (Table 2). Of 8 species recorded in 1935 and the 1950 's, only 2 were encountered in 1980 . Two species not previously encountered were present in 1980 . Total forb densities were equivalent to $0.5,2.1,1.4$ and 1.0 plants per $\mathrm{m}^{2}$ in 1935 , 1950,1955 and 1980, respectively. Broom snakeweed increased greatly in frequency percentage between 1955 and 1980 (Table 2). Densities of broom snakeweed were equivalent to 0.6 and 4.9 plants per $\mathrm{m}^{2}$ in 1935 and 1980 , respectively.

Major changes in vegetation occurred on the grassland portion of the transect in the 45-year period. Frequency percentage of mesquite canopy increased 10-fold over the entire period, doubling from 1955 to 1980 (Table 2). Black grama had a high frequency in $1935(70.9 \%)$ but declined sharply in abundance between 1950 and 1955. By 1980, black grama had disappeared from the area. Mesa dropseed showed a slight decrease in frequency percentage between 1935 and 1950. However, it increased in abundance between 1950 and 1955 and by 1980 had a frequency of $20.5 \%$. Fluffgrass was not present in 1935 or 1950 but by 1980 was nearly as abundant as mesa dropseed (Table 2). The density of mesa dropseed in 1980 was nearly equal on dune and interdune areas, being equivalent to 2.7 and 2.9 plants per $\mathrm{m}^{2}$, respectively. Fluffgrass had densities of 1.0 and 3.5 plants per $\mathrm{m}^{2}$ on dune and interdune areas, respectively.

Forbs were relatively more abundant on the grassland portion of the transect than on the mesquite duneland portion. Only 3 of the
13 forb species recorded from $1935-55$ were encountered in 1980 (Table 2). One forb species not present in earlier years was found in 1980. Total forb densities were equivalent to $3.2,2.4,2.5$, and 2.4 plants per $\mathrm{m}^{2}$ in $1935,1950,1955$, and 1980, respectively. Broom snake weed densities were equal to 0.7 plants per $\mathrm{m}^{2}$ in 1935 and 4.6 plants per $\mathrm{m}^{2}$ in 1980 .

Soaptree yucca declined in abundance on the grassland transect but was still present in 1980. Ephedra (Ephedra torreyana Wats.) was present on the transect in 1935 but was not found thereafter.

The disappearance of black grama from both the mesquite and grassland portions of the Site B transect and from Site A in the short time span of 45 years is striking. Probably the demise of black grama is not wholly due to the spread of mesquite. The susceptibility of black grama to drought has been documented in several investigations (Nelson 1934, Paulsen and Ares 1962, Herbel et al. 1972). The drought of 1934 caused a large reduction in black grama cover on many parts of the Experimental Range by 1936 (Paulsen and Ares 1962). Dead, as well as living, black grama plants are shown on the 1935 transect maps and the 1935 living plant frequencies reflect a declining population.

Black grama had the greatest loss in abundance between 1950 and 1955. This period coincided with the 1951-56 drought which was the most severe in the recorded history of the Southwest (McDonald 1956). At a rain gauge located approximately $2.8 \mathrm{~km}$ from the Site B transect, the mean annual precipitation for 1950-55 was $123 \mathrm{~mm}$ as compared to the long-term average of $231 \mathrm{~mm}$. Since there was less precipitation in 1956 than in 1955 or 1954 , it is likely that black grama suffered further severe losses immediately

Table 2. Frequency percentage of perennial plant species in $0.09 \mathrm{~m}^{2}$ plots of the Site $B$ transect in 1935, 1950, and 1980. The transect has been divided into what was mesquite duneland and grassland in 1935 .

\begin{tabular}{|c|c|c|c|c|c|c|c|c|}
\hline & \multicolumn{4}{|c|}{$\begin{array}{l}\text { Mesquite portion } \\
\quad(\mathrm{N}=750)\end{array}$} & \multicolumn{4}{|c|}{$\begin{array}{c}\text { Grassland portion } \\
(\mathrm{N}=650)\end{array}$} \\
\hline & 1935 & 1950 & 1955 & 1980 & 1935 & 1950 & 1955 & 1980 \\
\hline \multicolumn{9}{|l|}{ Grasses } \\
\hline Aristida spp. & .3 & 0 & 0 & 0 & 0 & 0 & .2 & 0 \\
\hline $\begin{array}{l}\text { Bouteloua eriopoda (Torr.) Torr. } \\
\text { Erioneuron pulchellum (H.B.K.) }\end{array}$ & 27.2 & 19.5 & .9 & 0 & 70.9 & 56.3 & 8.6 & 0 \\
\hline Tateoka & 0 & 0 & 0 & 17.3 & 0 & 0 & .2 & 17.9 \\
\hline Muhlenbergia porteri Scribn. & .3 & 0 & .4 & .7 & 0 & 0 & .3 & 0 \\
\hline Panicum spp. & 0 & 0 & 0 & 0 & 0 & 0 & .3 & 0 \\
\hline $\begin{array}{l}\text { Sporobolus contractus Hitchc. } \\
\text { Sporobolus flexuosus (Thurb.) }\end{array}$ & 0 & 0 & .1 & 0 & 0 & 0 & 0 & 0 \\
\hline Rydb. & 6.3 & 2.0 & 9.6 & 15.5 & 3.7 & 2.8 & 7.9 & 20.5 \\
\hline \multicolumn{9}{|l|}{ Forbs } \\
\hline Astragalus spp. & .1 & 0 & 0 & 0 & .8 & 0 & 0 & 0 \\
\hline Caesalpinia jamesii (T. \& G.) Fisher & .1 & 0 & 0 & 0 & 1.2 & 0 & 0 & 0 \\
\hline $\begin{array}{l}\text { Cassia bauhinioides Gray } \\
\text { Chamaesaracha sordida (Dun.) }\end{array}$ & .1 & 0 & .4 & .6 & .2 & .5 & 2.6 & 8.5 \\
\hline Gray & 0 & 3.2 & 0 & 0 & 0 & 0 & 0 & 0 \\
\hline Croton pottsi (Kl.) Muell. & 1.7 & 8.9 & 7.6 & 1.5 & .5 & 8.3 & 9.7 & 8.6 \\
\hline Dalea spp. & $\mathbf{0}$ & 0 & 0 & 0 & 0 & 0 & .6 & 0 \\
\hline Euphorbia albomarginata T. \& G. & $\mathbf{0}$ & 0 & 0 & 0 & 0 & 4.3 & 0 & 0 \\
\hline Hoffmannseggia glauca (Ort.) Eifert & $\mathbf{0}$ & 0 & 0 & .1 & .5 & 2.9 & 1.1 & .6 \\
\hline Hymenopappus robustus Greene & 1.1 & 0 & 0 & 0 & 2.5 & 0 & 0 & 0 \\
\hline Lesquerella fendleri (Gray) Wats. & $\mathbf{0}$ & 0 & .9 & 0 & 13.9 & .3 & 4.5 & 0 \\
\hline Melampodium leucanthum T. \& G. & 0 & 0 & 0 & 0 & 0 & 0 & .9 & 0 \\
\hline Mentzelia multiflora (Nutt.) Gray & .7 & 0 & 0 & 0 & 2.9 & 0 & 0 & 0 \\
\hline Psilostrophe tagetina (Nutt.) Greene & 0 & 0 & 0 & 0 & 0 & 0 & .3 & 0 \\
\hline Solanum elaeagnifolium Cav. & 0 & 0 & 0 & 0 & 0 & 0 & 0 & .6 \\
\hline Sphaeralcea incana Torr. & 0 & 0 & 0 & .5 & 0 & 0 & .2 & 0 \\
\hline \multicolumn{9}{|l|}{ Shrubs and Shrub-like Plants } \\
\hline Atriplex canescens (Pursh) Nutt. & 0 & 0 & 0 & .1 & 0 & 0 & 0 & 0 \\
\hline Ephedra torreyana Wats. & .1 & 0 & 0 & 0 & .3 & 0 & 0 & 0 \\
\hline Prosopis glandulosa Torr. & $16.4^{1}$ & 25.31 & 26.91 & $32.8^{1}$ & 2.51 & 8.91 & $12.8^{\prime}$ & 24.81 \\
\hline Yucca elata Engelm. & 0 & 0 & 0 & 0 & 1.1 & 1.7 & 1.4 & .6 \\
\hline Xanthocephalum sarothrae & & & & & & & & \\
\hline (Pursh) Shinners & 3.7 & 4.8 & 4.1 & 30.4 & 5.2 & 2.3 & 2.9 & 28.9 \\
\hline
\end{tabular}

'Frequency percentage of mesquite canopy. 
following the 1955 sampling.

The death of black grama permitted other species to occupy the former grassland. Mesquite increased steadily, even during the drought of the 1950's, and probably hastened the loss of black grama. Mesa dropseed increased in both drought and postdrought years. Fluffgrass and broom snakeweed both increased greatly in the $1955-80$ period. Two forbs, twin-leaf senna (Cassia bauhinioides Gray) and leatherweed croton [Croton pottsi (Kl.) Muell.] exhibited both drought resistance and the ability to increase in abundance in the face of increased competition from mesquite.

That drought is a major factor in the spread of mesquite, as asserted by Buffington and Herbel (1965) and Fisher (1977), is probably correct but the spread of mesquite in southern New Mexico probably proceeded as follows: (a) drought stressed black grama to a point where some individuals died and reproduction, not being efficient in black grama, suffered severely; (b) in favorable years, open areas in the black grama community were occupied by mesquite and other grass and forb species from nearby areas before black grama could reoccupy the open areas; (c) establishment of mesquite drastically modified the site so that extensive soil movement occurred and dunes formed; and (d) site modification resulted in a less favorable soil water regime and the competition from mesquite and other plants rendered the site effectively inaccessible to black grama establishment.

Wright and Van Dyne (1981) in their simulation of mesquite "invasion," which is based on Jornada Experimental Range quadrat records, found that mesquite would totally dominate a model black grama community within 30 years. Their time frame is realistic but not all of their conclusions appear tenable in light of the data presented here. They claim an inverse relationship between mesquite density and grass abundance. Such generalization certainly does not apply to mesa dropseed and fluffgrass. The relationship between grasses and mesquite is perhaps better characterized as a bimodal one with a sharply declining segment as black grama dies out and then a positive relationship between the increase of mesquite and the increase in abundance of mesa dropseed and fluffgrass. Wright and Van Dyne (1981) also say that though some plants become established each year, the "harsh" micro-climate of the interdune area quickly eliminates them. The implication that the interdune area is for the most part devoid of vegetation, though a common perception, is not supported by the data presented here. Mesa dropseed, fluffgrass, broom snakeweed, and a few perennial forbs appear to be able to reproduce and readily survive in interdune areas, both in dry and wet years.

The spread of mesquite into the former black grama grassland has led to the displacement of many forb species and some shrubs. The remaining perennial herbaceous species seem to be well adapted for survival in the mesquite duneland situation. Their abundance will undoubtedly oscillate with wet and dry climatic cyles. The long-lived mesquite appears well adapted to the existing climatic regime and will probably maintain its population at existing levels for many years.

\section{Literature Cited}

Bullock, H.E., Jr., and R.E. Neher. 1980. Soil survey of Dona Ana County area New Mexico. USDA, Soil Conserv. Serv.

Bumngton, L.C., and C.H. Herbel. 1965. Vegetational changes on a semidesert grassland range from 1858 to 1963 . Ecol. Monog. 35:139-164.

Correll, D.S., and M.C. Johnston. 1970. Manual of the vascular plants of Texas. Texas Research Foundation, Renner, Texas.

Dittberner, P.L. 1971. A demographic study of some semidesert grassland plants. M.S. Thesis. New Mexico State Univ., Las Cruces.

Fisher, C.E. 1977. Mesquite and modern man in southwestern North America. p. 117-188. In: B.B. Simpson (ed.) Mesquite, its biology in two desert shrub ecosystems. Dowden, Hutchinson and Ross Inc., Stroudsburg, Pa.

Gibbens, R.P., J.M. Tromble, J.C. Hennessy, and M. Cardenas. 1983. Soil movement in mesquite dunelands and former grasslands of Southern New Mexico from 1933 to 1980. J. of Range Manage. 36:145-148.

Gile, L.H. 1966. Coppice dunes and the rotura soil. Soil Sci. Soc. Amer. Proc. 30:657-660.

Glendening, G.E., and H.A. Paulsen, Jr. 1955. Reproduction and establishment of velvet mesquite as related to invasion of semidesert grasslands. USDA Tech. Bull. No. 1127.

Herbel, C.H., and W.L. Gould. 1970. Control of mesquite, creosotebush, and tarbush on arid rangelands of the southwestern United States. Proc. XI Internat. Grassl. Cong., p. 38-41.

Herbel, C.H., F.N. Ares, and R.A. Wright. 1972. Drought effects on a semidesert grassland range. Ecology 53:1084-1093.

McDonald, J.E. 1956. Variability of precipitation in an arid region: A survey of characteristics for Arizona. Tech. Rep. on the meteorology and climatology of arid regions, No. 1. Inst. Atmos. Phys., Univ. Arizona, Tucson.

Melton, F.A. 1940. Classification of sand dunes. J. Geol. 48:113-174.

Mooney, H.A., B.B. Simpson, and O.T. Solbrig. 1977. Phenology, morphology, physiology. p. 26-43. In: B. B. Simpson (ed.) Mesquite, its biology in two desert shrub ecosystems. Dowden, Hutchinson and Ross Inc., Stroudsburg, $\mathrm{Pa}$.

Nelson, E.W. 1934. The influence of precipitation and grazing upon black grama grass range. USDA Tech. Bull. No. 409.

Paulsen, H.A., Jr., and F.N. Ares. 1962. Grazing values and management of black grama and tobosa grasslands and associated shrub ranges of the Southwest. USDA, Forest Serv. Tech. Bull. No. 1270.

Wright, R.G., and G.M. Van Dyne. 1981. Population age structure and its relationship to the maintenance of the semidesert grassland undergoing invasion by mesquite. Southwestern Natur. 26:13-22.

York, J.C., and W.A. Dick-Peddie. 1969. Vegetation changes in southern New Mexico during the past hundred years. p. 157-166. In: W.G. McGinnies and B.J. Goldman (ed.) Arid lands in perspective. Univ. Arizona press, Tucson, Ariz. 


\title{
Relationship between Cutler Mormon-Tea [Ephedra cutleri] and Coppice Dunes in Determining Range Trend in Northeastern Arizona
}

\author{
HARMON S. HODGKINSON
}

\begin{abstract}
Range trend is one of the basic components of rangeland inventories. Understanding the interactions between soil, climatic factors, and vegetation aids the range manager in determining and predicting trend. Coppice dunes, dune interspace, and vegetation were evaluated in northeastern Arizona. Soil with a surface layer of loamy fine sand is susceptible to wind erosion. If Cutler Mormontea is part of the plant community, coppice dunes may form. Range trend can be determined and predicted by observing the status of the coppice dunes, the dune interspace, and their vegetation.
\end{abstract}

Range managers make inventories that are used to develop quality range management plans. Range condition and trend are two basic components of the inventory. Range condition is the present state of vegetation in relation to the natural potential plant community for the site. Range trend is a determination of the direction of change in range condition or what is currently happening to the plant community.

Interactions between soil and vegetation are important in understanding range trend. If the range manager can understand the cause of soil movement and the reaction of vegetation, current range trend can be better determined and gross trend changes can be predicted. Many rangelands in low precipitation areas are unable to support a complete plant cover. Bare ground is natural and provides a source for some local soil movement. However, any decreases in plant cover will accelerate soil surface movement.

The purpose of this study was to evaluate the soil and vegetation on coppice dunes and dune interspaces in order to understand how the dunes and vegetation might be related to current range trend and gross trend changes.

\section{Study Area}

The study was conducted during the summer of 1981 on the Hopi Indian Reservation in central Navajo County, Ariz. The study site is about $105 \mathrm{~km}$ (65 miles) northeast of Flagstaff and is part of the Colorado and Green River Plateau major land resource area. The area is typified by long, broad rolling mesas and plains dissected by major drainages. The closest villages are Oraibi, 35 kilometers (22 miles) north, and Seba Dalkai, 18 kilometers (11 miles) southeast on the Navajo Indian Reservation. Annual precipitation at Oraibi is 195 millimeters (7.69 inches) and at Seba Dalkai 184 millimeters ( 7.24 inches). About $55 \%$ of the annual precipitation is received in summer thundershowers that are typical of storms in the Southwest. The other $45 \%$ falls as snow in the winter months. June is the driest month. Mean annual temperature at

Author is range conservationist, Soil Conservation Service, 2717 North Fourth Street Suite 140, Flagstaff, Ariz. 86001

The author thanks Robert J. Ahrens and Deborah J. McKeown, Soil Scientists, SCS, Flagstaff, for assistance with the soil evaluation.

Manuscript received April 15, 1982.
Oraibi is $10.9^{\circ}$ C. $\left(51.9^{\circ}\right.$ F.) and at Seba Dalkai $11.7^{\circ}$ C. $\left(53.4^{\circ}\right.$ F.). The elevation at the study site ranges from 1615 meters ( 5300 feet) to $1706 \mathrm{~m}$ ( 5600 feet). Drying winds in spring are generally from a southwestern direction.

\section{Methods}

\section{Vegetation}

The present plant communities were evaluated on the coppice dunes and dune interspaces. Care was taken to sample each plant community separately. Plant composition and yield were determined by the "double-sampling" method used by the Soil Conservation Service (USDA 1976). In the procedure, $10-1-\mathrm{m}^{2}(9.6 \mathrm{sq} . \mathrm{ft}$.) plots were randomly selected on the area to be sampled. All plant species were estimated by weight for each plot. Individual species on the 2 most representative plots were harvested and weighed. Plot correction factors were applied to the estimations.

Soils

Pits were dug $165 \mathrm{~cm}$ (65 inches) deep with a backhoe in the coppice dune and the dune interspace for comparison. Soil characteristics were determined by methodology given in the Soil Survey Manual (Soil Survey Staff 1951), and Soil Taxonomy (Soil Survey Staff 1975). The soil in the coppice dune and in the dune interspace areas both are of the Sheppard series, a member of the mixed, mexic Typic Torripsamments.

\section{Results and Discussion}

A landscape that has coppice dunes or the potential for coppice dunes must have soil that is susceptible to wind movement, wind, and vegetation that will withstand deposition.

Coppice dunes are soil deposits formed by wind in conflict with bunch or clump vegetation (Melton 1940). Dunes develop within or to the leeward side of plants that can withstand rapid soil deposition. In Nevada, Wood et al. (1978) found that coppice dunes formed from silt and very fine sands. Near Las Cruces, New Mexico, Gile and Grossman (1979) found that soils that have a sand, loamy sand, or light sandy loam surface layer form coppice dunes. The area between the coppice dunes is defined as dune interspace (Melton 1940).

The Sheppard soil on this study site has a texture of loamy fine sand. It formed from the Navajo Sandstone formation that is extensive in this area.

The soils, whether in the coppice dunes or the dune interspace, were described identically with the exception of surface structure. On the coppice dune, the structure to a depth of $5 \mathrm{~cm}$ ( 2 inches) is weak thin platy over weak fine subangular blocky. On the dune interspace, the structure to a depth of $13 \mathrm{~cm}$ (5 inches) is weak 
medium and thick platy over weak fine and medium subangular blocky.

Another difference between the Sheppard soil in the coppice dune and that in the dune interspace is the depth of the recent depositional layer. In the coppice dune the depth ranged from 30 to $92 \mathrm{~cm}$ ( 12 to 36 inches); in the dune interspace, it ranged from 7.6 to $13 \mathrm{~cm}$ ( 3 to 5 inches).

The height of the coppice dune is related to the amount of erosion and deposition that has occurred. Anderson (1974) states that the difference between a mound and an adjacent scoured area represents both erosion and deposition.

Past soil movement is evident in the topography of the Sheppard soil (Fig. 1). The coppice dunes on the study site have an average height of $0.9 \mathrm{~m}$ ( $3 \mathrm{feet})$, with a minimum of $0.6 \mathrm{~m}$ ( 2 feet) and a maximum of $1.8 \mathrm{~m}$ (6 feet). The average diameter is $6.1 \mathrm{~m}(20 \mathrm{feet})$ with a minimum of $3.0 \mathrm{~m}$ ( $10 \mathrm{feet})$ and a maximum of $13.7 \mathrm{~m} \mathrm{(45}$ feet). The dune interspace averages $12.1 \mathrm{~m}$ (40 feet) with a minimum of $30 \mathrm{~m}$ (10 feet) and a maximum of $18.3 \mathrm{~m}$ (60 feet).

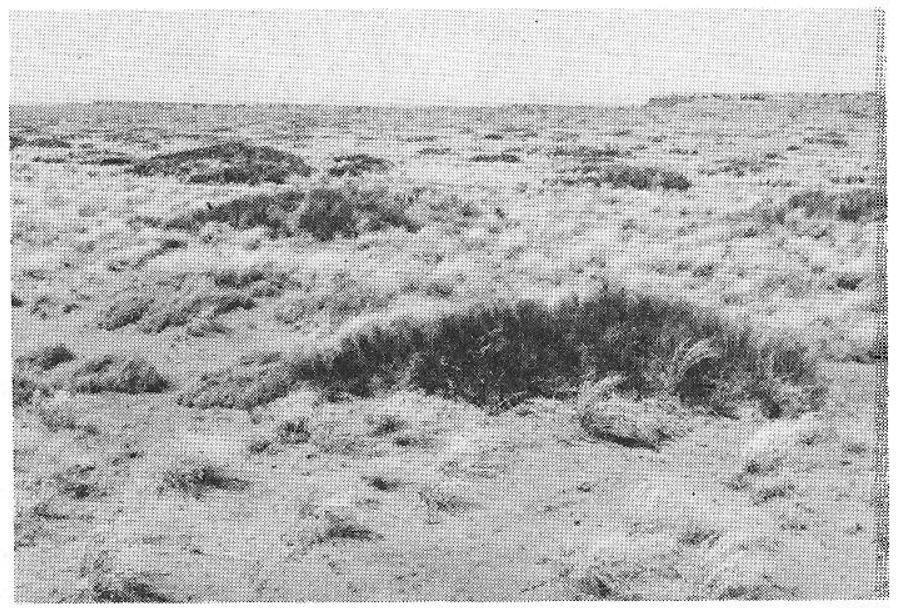

Fig. 1. Coppice dunes are dominated by Cutler Mormon-tea indicating past wind erosion on Sheppard soil. Indian ricegrass is the major species of the dune interspace.

Wind is the second requirement for the formation of coppice dunes. The closest weather station recording representative wind speeds is at Winslow, about 80 kilometers (50 miles) south of the study site (Sellers and Hill 1974). The study area lies in the windiest part of the state where sandstorms are quite common in late winter and spring. Also, strong winds usually precede summer thunderstorms capable of causing wind erosion. The strongest maximum winds range from $64.3 \mathrm{~km} /$ hour $(40.0 \mathrm{mph})$ to $73.2 \mathrm{~km} /$ hour $(45.5$ $\mathrm{mph}$ ) occurring in late winter and spring afternoons. The winds that precede summer thunderstorms reach a maximum of 55.8 $\mathrm{km} /$ hour (34.7 $\mathrm{mph}$ ) in the afternoon.

Plants that survive on coppice dunes are those adapted to loose aeolian deposits and typically have rhizomes. In southern New Mexico, Gile and Grossman (1979) found mesquite (Prosopis juliflora) to be the dominant plant on coppice dunes, with an occasional fourwing saltbush (Atriplex canescens). Cutler Mormon-tea (Ephedra cutleri), an evergreen shrub that has strong rhizomes, was the major plant on the coppice dunes in the study site (Table 1). Like mesquite, Cutler Mormon-tea can withstand rapid soil deposition. Indian ricegrass (Oryzopsis hymenoides), broom snakeweed (Guiterrezia sarothrae), and fourwing saltbush were also present in minor amounts.

Cutler Mormon-tea is a minor part of the potential plant community for the undisturbed Sheppard soil (Fig. 2). The shrub is inconspicuous with Indian ricegrass the major grass species. After erosion occurs and coppice dunes are formed, the Mormon-tea becomes extremely visible (Figure 3). On the dune interspace, Indian ricegrass, galleta (Hilaria jamesii), and broom snakeweed are the major plants (Table 1).
Table 1. Species, composition, and total annual yield in Coppice Dune and Dune Interspace Soils.

\begin{tabular}{|c|c|c|c|}
\hline \multicolumn{2}{|c|}{ Species } & \multicolumn{2}{|c|}{$\begin{array}{l}\text { Composition (\%) } \\
\text { (air-dry weight) }\end{array}$} \\
\hline Common Name & Scientific Name & Dune & Interspace \\
\hline \multicolumn{4}{|c|}{ Grasses } \\
\hline Fendler threeawn & Aristida fendleriana & & 1 \\
\hline Galleta & Hilaria jamesii & & 5 \\
\hline Sandhill muhly & Muhlenbergia pungens & & $I$ \\
\hline Indian ricegrass & Oryzopsis hymenoides & 25 & 81 \\
\hline Mesa dropseed & Sporobolus flexuosus & & 1 \\
\hline Needleandthread & Stipa comata & & 1 \\
\hline \multicolumn{4}{|c|}{ Forbs } \\
\hline Heath aster & Leucelene ericoides & & 1 \\
\hline Russian thistle & $\begin{array}{l}\text { Salsola kali var. } \\
\text { tenuifolia }\end{array}$ & 1 & 1 \\
\hline $\begin{array}{l}\text { Smallflower } \\
\text { globemallow }\end{array}$ & Sphaeralcea parvifolia & 1 & \\
\hline Golden crownbeard & $\begin{array}{r}\text { Verbesina encelioides } \\
\text { var. exauriculata }\end{array}$ & 1 & \\
\hline \multicolumn{4}{|c|}{ Shrubs } \\
\hline Fourwing saltbush & Atriplex canescens & 1 & 1 \\
\hline Cutler Mormon-tea & Ephedra cutleri & 68 & \\
\hline Winterfat & Durotia lanata & & 1 \\
\hline Broom snakeweed & Gutierrezia sarothrae & 3 & 5 \\
\hline Fineleaf yucca & Yucca angustissima & & 1 \\
\hline \multicolumn{2}{|c|}{ Total percentage 100} & 100 & 100 \\
\hline otal annual yield & $(\mathrm{lb} / \mathrm{ac})$ & $(260)$ & $409(365)$ \\
\hline
\end{tabular}

To determine trend in range condition, several factors must be evaluated to know whether the plant community and soil changes are improving (upward trend) or declining (downward trend) from the potential for the site. After determining trend, the proper use, management, and treatment of the resource can be planned and applied.

The major factors used to indicate trend are the abundance of seedlings and young plants, plant vigor, species composition changes, plant residues and the condition of the soil surface (presence or absence of erosion). All or several factors must be considered in relation to each other for a sound determination of trend. The importance of these factors vary accordingly to different climate, soils, vegetation and the past and/or present grazing management.

There is much conjecture as to the cause of erosion in the Southwest. Most researchers (Thornthwaite et al. 1942, Antevs 1952) believe a combination of drought and overgrazing leaves the soil surface vulnerable to wind and water erosion.

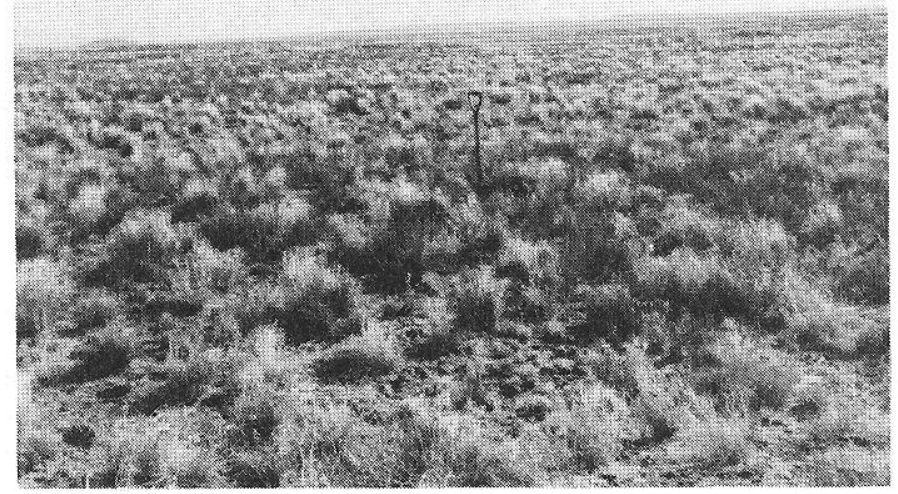

Fig. 2. The potential plant community on the undisturbed Sheppard soil is a mixture of Cutler Mormon-tea and Indian ricegrass. Tile spade height is $114 \mathrm{~cm}$ (45 inches). 


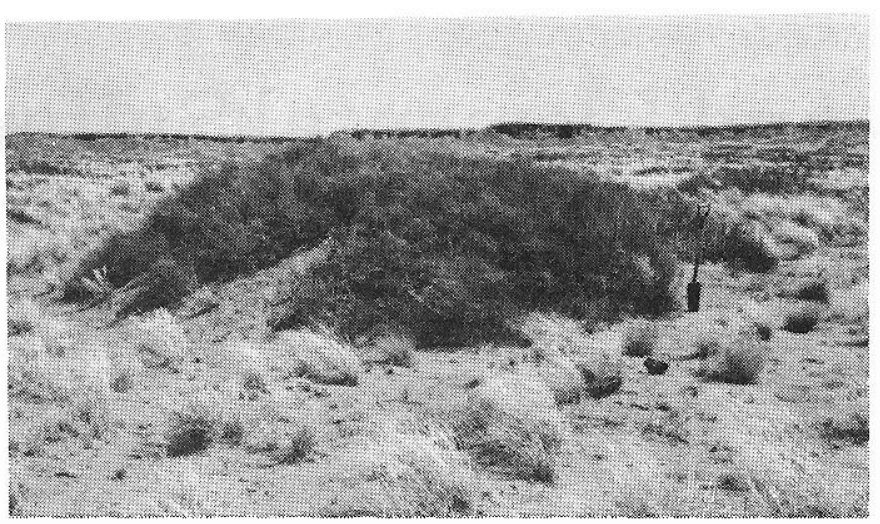

Fig. 3. Coppice dune $130 \mathrm{~cm}$ (5I inches) high covered with Cutler Mormon-tea. Tile spade height is $114 \mathrm{~cm}$ (45 inches).

A natural plant community develops in equilibrium with its given climate. Plants may increase or decrease in size and frequency as the climate fluctuates. Where precipitation is low, vegetation may just barely protect the soil surface from excessive erosion. The margin to protect the soil is slight. Only light grazing and in some cases, no grazing can be permitted and still provide soil protection by the vegetation in drought years. Bryan (1950) concluded that "overgrazing appears to have been merely a trigger pull which timed the explosive proccess that was imminent from climatic causes."

In this study, only the soil factor (coppice dunes) in relation to the plant community were evaluated in determining trend. However, it can be deducted that the presence of coppice dunes on the Sheppard soil indicates the range trend at sometime declined and still may be declining depending on other factors such as if the dune interspace is stabilized with undesirable or foreign plants to the potential plant community. Where there are no coppice dunes or none forming (the Cutler Mormon-tea being elevated by soil deposition), the range trend generally will be improving.

\section{Conclusion}

Range managers are better qualified in determining range trend and predicting gross trend changes through understanding the interactions of the soil, climatic factors, and vegetation.

In northeastern Arizona, soils susceptible to wind erosion must be managed carefully. Coppice dunes will form in areas of low precipitation, if the soils have a loamy fine sand surface layer, if there is considerable wind, if vegetation has been depleted, and if Cutler Mormon-tea is part of the plant community. Based on this criteria, where coppice dunes are forming, the range trend is down. If the coppice dunes have already formed and the dune interspace is stabilized with desirable plants of the potential plant community, the range trend is generally up.

\section{Literature Cited}

Anderson, E. William. 1974. Indicators of soil movement on range watersheds. J. Range Manage. 223:244-247.

Antevs, Ernst. 1952. Arroyo cutting and filling. J. of Geology. 60:375-385. Bryan, Kirk. 1950. Geologic interpretation of the deposits. In: Haury, E.W., the stratigraphy and archeology of Ventana Cave, Arizona. Univ. New Mexico Press. Albuquerque. p. 75-126.

Gile, Leland H., and Robert B. Grossman. 1979. The desert project soil monograph. USDA-SCS.

Melton, Frank A. 1940. A tentative classification of sand dunes: its application to dune history in the southern High Plains. J. Geology 48:113-174.

Sellers, William D., and Richard H. Hill. 1974. Arizona climate, 1931-1972. The Univ. Arizona Press; Tucson.

Soil Survey Staff. 1951. Soil survey manual. USDA Agr. Handbook No. 18.

Soil Survey Staff. 1975. Soil taxonomy; a basic system of soil classification for making and interpreting soil surveys. USDA Agr. Handbook No. 436.

Thornthwaite, C.W., C.F.S. Sharpe, and E.F. Dosch. 1942. Climate and accelerated erosion in the arid and semiarid Southwest, with special reference to the Polacca Wash drainage basin, Arizona. USDA Tech. Bull. 808 .

U.S. Department of Agriculture. 1976. National range handbook. Soil Conserv. Ser.

Wood, M.K., W.H. Blackburn, R.E. Eckert, Jr., and F.F. Peterson. 1978. Interrelations of the physical properties of the coppice dune and vesicular dune interspace soils with grass seedling emergence. J. Range Manage. 31:189-192. 